\title{
Systeemien itseuudistuminen - uutta ymmärrystä kollektiivien kehittymiseen
}

\author{
PIRJO STÅHLE \& TUOMO KUOSA
}

\begin{abstract}
Itseorganisoituminen ja itseuudistuminen viittaavat kollektiiviseen toimintaan ja älykkyyteen, joka ilmenee enemmän yhteisön kuin yksilön toiminnassa samalla tapaa kuin ns. parviäly eläinmaailmassa. Kirjoittajat tarkastelevat artikkelissaan systeemien itseuudistumista kolmen teorian kautta. Artikkelin ensisijaisena tavoitteena on luoda ymmärrystä siitä, mitä systeemien sisäsyntyinen, autonominen uudistuminen tarkoittaa ja millaisia universaaleja periaatteita sen toiminnasta on esitetty. Kirjoittajat tarkastelevat lopuksi myös teorioiden merkitystä käytännön kannalta.
\end{abstract}

\section{Kompleksinen, nopeasti muuttuva ympäristö pakottaa uudistumaan}

Globalisaatio ja tietoteknologia ovat tehneet sosiaalisesta toiminnasta yhä kompleksisempaa. Epälineaarisuus ja turbulenssi ovat lisääntyneet ja muuttaneet onnistumisen ja selviämisen keinoja yhteiskunnan kaikilla tasoilla (Eisenhardt \& Tabrizi, 1998). Toiminta on muuttunut kautta linjan verkostomaiseksi, kuten Manuel Castells jo 1996 ennusti kirjassaan The Rise of the Network Society. Globalisoitumisen myötä organisaatioiden joustavuudesta on tullut kilpailuetu, mikä on johtanut hierarkioiden mataloitumiseen tai purkautumiseen sekä yritysten että valtioiden tasolla. Kehityksen myötä kaikilta sosiaalisilta systeemeiltä vaaditaan entistä enemmän itseohjautuvuutta ja kykyä reflektoida omaa toimintaansa ja sen seurauksia itseä laajemmasta näkökulmasta. Nykymaailmassa ei ole enää yhtä (tai kahta) dominoivaa valtakeskusta (kirkko, tiede, politiikka), vaan maailma on muuttunut yhä enemmän itseorganisoituvaksi, moninapaiseksi ja kompleksiseksi systeemiksi. Tulevaisuuden kehitystä ennakoitaessa onkin nostettu esiin tarve uudenlaiseen toimintalogiik- kaan, jossa avaimena on systeemien ja yhteisöjen kyky itseohjautumiseen ja sisältä tapahtuvaan jatkuvaan uudistumiseen. Ilmiötä on viime vuosina tutkittu mm. itseorganisoitumisen, itseuudistumisen ja kollektiivisen oppimisen näkökulmasta.

Etenkin sosiaali- ja organisaatiotieteiden piirissä itseorganisoituminen on herättänyt viime vuosina runsaasti kiinnostusta. Suomessa Kai Hakkarainen (2006) ja Yrjö Engeström kollegoineen ovat tutkineet ilmiötä kollektiivisen älykkyyden kontekstissa. Organisaatioiden uudistumisen näkökulmasta teemaa ovat tarkastelleet Pirjo Ståhle (1998, Ståhle ym. 2003) ja Aino Kianto (Pöyhönen 2005) sekä kompleksisten adaptiivisten systeemien näkökulmasta Marjatta Maula (1999). Myös verkostojen itseorganisoituminen, bisnes-ekosysteemien muodostuminen ja innovaatiodemokratia ovat olleet viime vuosina esillä kansainvälisessä keskustelussa (Chesbrough, 2006; von Hippel, 2005).

Mitä itseorganisoituminen ja itseuudistuminen sitten tarkoittavat? Ne viittaavat kollektiiviseen toimintaan ja älykkyyteen, joka ilmenee enemmän yhteisön kuin yksilön toiminnassa samaan tapaan kuin ns. parviäly eläinmaailmassa. Sosiaalisilla yhteisöillä on mahdollisuus luoda yhteistä tietoa 
ja osaamista, joka ylittää yksilöllisen tietotaidon rajat (Hakkarainen, 2006). Engeströmin mukaan on jopa syntynyt historiallisesti uusi verkostojen rajapinnoissa tehtävän työn muoto, solmutyöskentely (knotworking). Tämä tarkoittaa sitä, että työntekijät organisoivat työnsä, tavoitteensa ja toimintaperiaatteensa keskinäisessä yhteistyössä, ja että työltä puuttuu ennalta organisoitu keskus (Engeström ym. 1999). Poliisin karhukopla, jalkapallojoukkue tai teho-osaston tiimi ovat hyviä esimerkkejä siitä, miten intensiivinen vuorovaikutus tekee mahdolliseksi kehittää kollektiivista tietämistä. On myös esitetty, että nykyinen tietoverkostojen aikakausi muuttaa käsityksiämme siitä, miten ihmisen äly ylipäänsä toimii. Nykyisen tutkimuksen perusteella näyttää yhä enemmän siltä, että ihminen on verkostoitunut ja kulttuurinen olento, jonka älykkyys on paitsi sosiaalisesti myös fysikaalisesti jakaantunut - eli älykkyys on osaltaan integroitunut myös tietoteknologiaan (Hakkarainen 2006, Weick \& Roberts, 1993, Salomon, 1993).

Vaikka itseuudistumisen teemaa on käsitelty paljon etenkin viime vuosina, sen teoreettiset juuret ovat paljon vanhempaa perua. Onkin syytä paneutua tarkastelemaan teorialähtöisesti, mitä itseuudistumisella tarkoitetaan, ettei asia jäisi metaforiselle tai ilmiön kuvausten tasolle - kuten paljolti tutkimuskirjallisuudessa on käynyt. Tässä artikkelissa pureudumme systeemien itseuudistumiseen kolmen teorian kautta. Ensin tarkastelemme itseorganisoitumista Ilya Prigoginen dissipatiivisten systeemien teorian pohjalta, sen jälkeen käsittelemme Humberto Maturanan ja Francisco Varelan esittämä autopoiesis-teoriaa, ja lopuksi nostamme esiin joitakin täydentäviä näkökulmia Stuart Kauffmanin tutkimuksista. Ensisijainen tavoitteemme on luoda ymmärrystä siitä, mitä systeemien sisäsyntyinen, autonominen uudistuminen tarkoittaa ja millaisia universaaleja periaatteita sen toiminnasta on esitetty. Artikkelimme lopussa tarkastelemme myös esimerkkejä siitä, mitä merkitystä näillä teorioilla on käytännön kannalta.

Prigoginen teoria on valittu yhdeksi artikkelin pääteoriaksi, koska sitä voidaan pitää edelleen ehkä parhaimpana kuvauksena itseorganisoituvien systeemien toiminnasta. Prigogine kuvaa periaatteita, joiden kautta systeemien emergenssi (laadullisesti uusi, palautumaton rakenne) itseorganisoituu hetkellisen kaaoksen pohjalta uudelleen. Prigoginen lähestymistapa on systeemiteoreetikoille tyypillisesti monitieteinen, ja hänen ansiokseen voidaan laskea orgaanisen maailman käsitteen tuomi- nen osaksi fysiikkaa ja kemiaa. Itseuudistumisen periaatteet ovat Prigoginen mukaan yleisiä ja ovat siten sovellettavissa myös sosiaalisiin systeemeihin (Prigogine, 1976, 120126)

Itseuudistuvien systeemien tutkimus ei ole kuitenkaan pysähtynyt Prigogineen. Hänen työnsä jälkeen - ja sen rinnalla - on tehty monia tärkeitä löydöksiä itseuudistuvista systeemeistä. Näistä ehkä merkittävin on Humberto Maturanan ja Fransesco Varelan esittämä autopoiesis-teoria. $^{3}$ Autopoiesista voidaan pitää itseorganisoitumisen rinnalla toisena, lähtökohdiltaan siitä erottuvana periaattee-

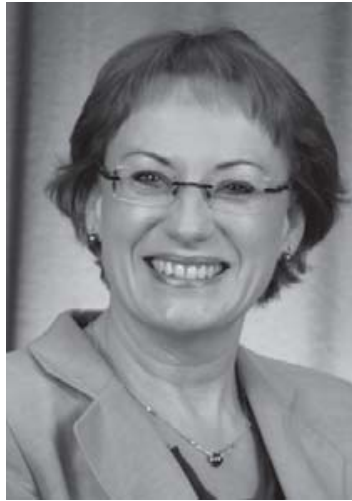

Pirjo Ståhle

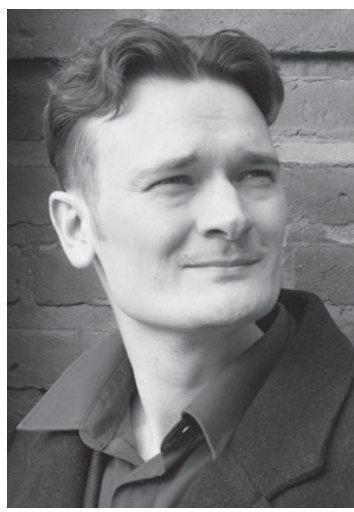

Tuomo Kuosa na, jonka kautta systeemit uudistavat itseään. Maturanan ja Varelan varsinainen anti ihmistieteiden näkökulmasta on se, että he nostivat esiin kysymyksen kognitioista ja tietämisestä myös perustavien elämänmuotojen (solu)tasolla: jotta solu kykenee syntymään ja uusiutumaan, sen pitää "tietää” itsestään (identiteetistään) ja ympäristöstään jotakin. Siten Maturana ja Varela ovat yhtä hyvin kognitiotieteilijoitä kuin biologeja.

Kolmas tässä artikkelissa esiteltävä kokonaisuus on Stuart Kauffman teoria. Se on valittu mukaan tähän tarkasteluun, koska sitä voidaan pitää ehkä oman aikamme merkittävimpänä autonomista uudistumista käsittelevien teorioiden päivittäjänä, joka on tuonut uusia näkökulmia sekä Prigoginen että Maturanan ja Varelan ajatteluun.

\section{Prigoginen itseorganisoituvat systeemit}

Brysselissa uransa tehnyt venäläinen kemisti Ilya Prigogine (1917-2003) julkaisi vuonna 1967 tutkimuksensa dissipatiivisista eli peruuttamattomasti 
itseorganisoituvista systeemeistä. Hän tutki niiden avulla syntymien prosessia (the process of becoming) ja järjestystä, joka syntyy kaaoksen pohjalta (order out of chaos) (Prigogine 1967a, 1967b, 1967c). Prigogine tutkimusryhmineen osoitti, että systeemit kykenivät tietyissä olosuhteissa organisoitumaan itsestään, ennakoimattomasti ja ilman ulkoa tulevaa kontrollia, ja että itseorganisoituminen on varsin yleinen systeemien ominaisuus (mm. Nicolis \& Prigogine, 1977, Prigogine \& Stengers, 1984). Prigoginen teorian taustalta voidaan löytää Charles Darwinin teoria, joka todisti lajien kehityksen pohjautuvan populaatiotasolla tapahtuvista muutoksista yksilötason sijaan, Ludwig Boltzmannin teoria, joka todisti kaasujen käytöksen johtuvan koko kaasupopulaation välisistä vuorovaikutuksista yksittäisten molekyylien sijaan sekä Henri Bénardin tutkimus lämmön vaikutuksista kaasujen käyttäytymiseen. Prigoginen tutkimustyö palkittiin kemian Nobelin palkinnolla 1977.

Prigogine on käsitellyt itsestään järjestäytymistä useissa teoksissaan eri näkökulmista ja erilaisin käsitteellisin konstruktioin. Kokonaiskuvan luomiseksi nostamme tässä esiin viisi käsitettä, joiden avulla Prigogine kuvaa itseorganisoitumisen edellytyksiä ja periaatteita. Nämä ydinkäsitteet ovat: 1)"kaukana tasapainosta” (far from equilibrium), 2) entropia, 3) iteraatio, 4) bifurkaatio ja 5) aika. Näiden ydinkäsitteiden kuvaus tässä perustuu pääosin esiin neljään julkaisuun: Order out of Chaos (Prigogine \& Stengers, 1984), From Being to Becoming (Prigogine, 1980), Thermodynamic Theory of Structure, Stability and Fluctuations (Glannsdorff \& Prigogine, 1971) ja Exploring Complexity (Prigogine \& Nicolis, 1989). Käsitteiden alkuperä on kemiallisissa ja fysikaalisissa ilmiöissä, mutta Prigogine viittaa useissa kohdin löytämiensä periaatteiden olevan universaaleja ja soveltuvan myös sosiaalisiin ja inhimillisiin systeemeihin (mm. Prigogine, 1976, 120-126; Prigogine \& Nicolis, 1989, 238-242).

Prigoginen mukaan suurin osa maailmassa ilmenevistä systeemeistä kykenee organisoitumaan itsestään, mutta ainoastaan tietyin edellytyksin: itseorganisoituminen voi tapahtua vain systeemeissä, jotka kykenevät olemaan kaukana tasapainosta. Mekaaniset tai avoimet, tasapainoiset systeemit ainoastaan hajoavat voimakkaan tasapainottomuuden seurauksena, eivätkä kykene muodostamaan uusia rakenteita. Prigoginen mukaan kaikissa elämän muodoissa kaaos tai tasapainottomuus on uuden järjestyksen lähde. Itse- organisoituva systeemi elää ikään kuin kaaoksen ja järjestyksen vuorottelevassa rytmissä. (Prigogine \& Stengers, 1984, 178, 278, 292; Prigogine, 1980, 100, 123.)

Entropialla tarkoitetaan energiaa tai informaatiota, jota systeemi tuottaa, mutta ei voi hyödyntää - eli kyse on tavallaan ylijäämästä. Korkea entropia-aste viittaa myös epäjärjestykseen, tuhlattuihin resursseihin, hyödyntämättömään informaatioon ja epävarmuuteen systeemin sisällä. Entropiaa syntyy silloin, kun systeemi vaihtaa informaatiota ja energiaa yli tarpeen tai (sosiaalisissa systeemeissä) informaatio on järjestäytymätöntä, luokittelematonta tai ei-arvotettua. Vakiintuneen näkemyksen ja termodynamiikan toisen lain mukaan entropiaa on totuttu pitämään systeemin kannalta hyödyttömänä. Prigogine kuitenkin osoitti, että itseorganisoitumiseen kykenevissä systeemeissä entropialla on aivan olennainen rooli. Se tuo mukanaan epävarmuutta, tasapainottomuutta ja "hämmennystä” systeemiin - ja juuri tämä epävakaus on perusehto sille, että systeemillä on mahdollisuus organisoitua itsestään. (Glandsdorff \& Prigogine, 1971).

Kaikkien itseorganisotuvien systeeminen perustana on runsas informaation vaihto eli runsas vuorovaikutus. Iteraatiolla tarkoitetaan jatkuvaa, äärimmäisen herkkää palauteprosessia tai toimintaa, jonka avulla systeemin tuottama informaatio ja sen muodostamat mallit välittyvät nopeasti kaikkialle systeemiin. Iteraation ansiosta systeemillä on kyky uudistaa itseään ja kopioida sisäisiä mallejaan mikrotasolta makrotasolle ja päinvastoin. Iteraatio on tavallaan koko systeemin voimakeskus. Jotta iteraatio toimisi systeemissä, sisäisen vuorovaikutuksen on täytettävä kaksi kriteeriä: ensinnäkin sen on oltava epälineaarista, ja toiseksi sen on perustuttava palautteeseen. Palauteperusta viittaa iteratiivisen dynamiikan perusehtoon, eli herkkään riippuvuuteen alkuperäisistä olosuhteista. (Prigogine \& Nicolis, 1989, 219; Prigogine, 1976, 95). Iteraatio tekee systeemistä spontaanin ja muutoksille herkän ja ilmenee usein "perhosefektinä”: ensin vaikutus näkyy pienessä osassa systeemiä, mutta etenee ja voimistuu vähitellen niin, että "perhosen siiven isku Brasiliassa voi synnyttää tornadon Texasissa” (Lorenz, 1993, 14). Tämä ei olisi mahdollista ilman systeemin osien välistä herkkää ja jatkuvaa edestakaista palauteprosessia. Iteraatio on systeemin uudistumisen varsinainen voima, koska se synnyttää koko ajan uutta informaatiota ja uusia rakenteita sekä kuljettaa 
vaikutuksen koko systeemin läpi. (Prigogine \& Stengers, 1984, 154; Prigogine \& Nicolis, 1989, 72)

Bifurkaatio on vyöhyke tai piste determinismin ja vapaan valinnan välillä. Bifurkaatio tarkoittaa sitä, että a) systeemin elämässä on tiettyjä aikoja, jolloin sillä on mahdollisuus tehdä uusia valintoja, b) valintojen lopputulosta ei voi ennustaa (edes teoriassa) ja c) valinnat ovat peruuttamattomia. Bifurkaatio tuottaa aina muutoksen, joka ei ole edellisen struktuurin looginen jatkumo (Prigogine, 1980, 105), ja siten bifurkaatio tapahtumana on aina myös innovaation lähde (Prigogine \& Nicolis, 1989, 74). Systeemin muutos uuteen tasapainotilaan tapahtuu äkkiä, ikään kuin hyppäyksenä. Bifurkaatiopisteessä systeemi hylkää valtavan määrän informaatiota, jolloin entropian määrä laskee ja syntyy uusi järjestys. Bifurkaatiopiste on avainkäsite silloin, kun puhtaan palautumattomista (irreversible) muutoksista itseorganisoituvissa systeemeissä. Bifurkaatio ei välttämättä vaadi kaaosta, vaan epätasapainon tila riittää sekä se, että tilanne on autenttisesti ennalta määräämätön (non-deterministic). Systeemin kehityspolku sisältää sarjan sekä vakaita vaiheita, joissa deterministiset lait vallitsevat, että epästabiileja vaiheita eli bifurkaatiopisteitä, joissa systeemi on valinnut yhtäkkiä uuden kehityssuunnan. Tämä sekoitus välttämättömyyksiä ja mahdollisuuksia muodostaa systeemin historian (Prigogine \& Stengers, 1984, 169).

Aika on systeemin kannalta sekä subjektiivinen että objektiivinen. Subjektiivinen aika tarkoit- taa sitä, että systeemi luo oman historiansa omien valintojensa kautta. Bifurkaatiot eivät luo ainoastaan uutta järjestystä, vaan varustavat systeemin samalla myös uusilla ominaisuuksilla ja rakenteilla. Entropian tuottaminen pakottaa systeemiä menemään jatkuvasti eteenpäin, kehittymään ja etsimään uusia muotoja. Tällainen evoluutio on systeemin sisään rakennettu olemisen tapa. Ajan kuluessa kaikki systeemin osat ja sen alasysteemit vievät yhdessä evoluutiota eteenpäin (Prigogine \& Stengers, 1984, 106; Prigogine, 1980, 127.) Luonnossa ja ihmiselämässä entropia tuottaa jatkuvaa kehitystä ja eteenpäin menoa, jossa on aina mukana toisaalta innovatiivinen, toisaalta deterministinen puoli. Ihminen elää välttämättömyyden ja luovuuden sekä olemisen ja joksikin tulemisen rajapinnoilla (being and becoming) (Prigogine \& Lefever, 1973, 132). Ajan rooli on itseorganisoituville systeemeille merkittävä; entropian kumuloituminen vie aikaa, informaation vaihtaminen vie aikaa, iteratiivinen palauteprosessi vie aikaa - ja bifurkaatiopisteillä on oma rajoitettu, ennakoimaton ja äkillinen ilmenemisaikansa. (Prigogine \& Nicolis, 1989, 242; Prigogine, 1976, 124)

\section{Maturanan ja Varelan autopoiesis}

Chileläisten biologien Humberto Maturanan ja Francisco Varelan luoman autopoiesis-teorian lähtökohta on biologiassa, mutta sen vaikutus on levinnyt laajalti monelle tieteenalalle. Näistä lienee

\begin{tabular}{|c|l|l|l|l|}
\hline $\begin{array}{l}\text { Itseorganisoitumisen } \\
\text { pääkäsitteet }\end{array}$ & Kaukana & $\begin{array}{l}\text { Entropia } \\
\text { tasapainosta }\end{array}$ & Iteraatio & Bifurkaatio \\
\hline Ominaisuus & $\begin{array}{l}\text { Jatkuvaa tai } \\
\text { ajoittaista }\end{array}$ & $\begin{array}{l}\text { turhaa ylijäämää, } \\
\text { ei voida suoraan } \\
\text { hyödyntää }\end{array}$ & $\begin{array}{l}\text { epälineaarista, } \\
\text { palautteeseen } \\
\text { perustuvaa }\end{array}$ & $\begin{array}{l}\text { välttämättömyy- } \\
\text { den ja vapauden } \\
\text { välissä }\end{array}$ \\
\hline Ilmenemismuoto & $\begin{array}{l}\text { heilahtelut, } \\
\text { systeemin } \\
\text { sisäiset risti- } \\
\text { riidat, systee- } \\
\text { min paineet }\end{array}$ & $\begin{array}{l}\text { runsas informaa- } \\
\text { tion vaihto, epä- } \\
\text { varmuuden ja } \\
\text { hämmennyksen } \\
\text { sietäminen }\end{array}$ & $\begin{array}{l}\text { reaktio- ja } \\
\text { palauteherkkyys } \\
\text { kyys, positiivi- } \\
\text { nen ja negatiivi- } \\
\text { nen palaute }\end{array}$ & oikea ajoitus \\
\hline $\begin{array}{l}\text { Merkitys } \\
\text { itseuudistumiselle }\end{array}$ & $\begin{array}{l}\text { radikaalin } \\
\text { muutoksen } \\
\text { perusedellytys }\end{array}$ & $\begin{array}{l}\text { uuden järjestyk- } \\
\text { sen luominen }\end{array}$ & $\begin{array}{l}\text { informaation ja } \\
\text { toimintamallit } \\
\text { leviävät nope- } \\
\text { asti kaikkialle } \\
\text { systeemiin }\end{array}$ & $\begin{array}{l}\text { innovaatio ja } \\
\text { uudet ratkaisut }\end{array}$ \\
\hline
\end{tabular}


merkittävin saksalaisen sosiologin Niklas Luhmannin teoria itseensä viittaavista systeemeistä (selfreferential systems) (esim. Luhmann, 1990a; 1990b; 1995). Maturana ja Varela korostavat systeemin ytimen merkitystä itseuudistumiselle: näkökulmana on jonakin oleminen ja tämän merkitys systeemin uudistumis- ja vaikutusvoimalle. Olemista ei nähdä kuitenkaan staattisena olotilana, vaan ennen kaikkea prosessina, jossa systeemi tuottaa itsensä ja luo itseään jatkuvasti. Täten autopoieettisen organisoitumisen päämäärä on systeemi itse ja sen olemassaolo, ei "tekeminen" tai "edustaminen”. Autopoiesis tarkoittaa systeemin tapaa ylläpitää itseään siten, että systeemin sisäinen järjestelmä säilyy. Tämä sisäinen organisoituminen on yhtä kuin systeemin identiteetti, jonka perusteella systeemi erottuu muista (systeemeistä), ja jonka pohjalta se voidaan identifioida. (vrt. Rapoport, 1986, 114).

Maturana ja Varela julkaisivat teoriansa autopoieettisista systeemeistä 1970-luvun alkupuolella. Teoria perustuu tutkimuksiin biologisista systeemeistä, mutta Prigoginen tapaan myös Maturana ja Varela ovat korostaneet autopoeettisten periaatteiden universaalia luonnetta - ja myös kehittäneet teoriaansa siihen suuntaan.

Termi autopoiesis tarkoittaa itsensä tuotantoa, itsensä ylläpitoa, samuutta ja harmoniaa (autos = itse, poiein = tehdä, tuottaa, säilyttää olemassaolo, tehdä uudelleen, käsitteellistää). Autopoiesis tarkoittaa itsensä tuottamisen (self-production) ja itseuudistumisen prosessia elävissä systeemeissä. Autopoieettisessa systeemissä sekä itse systeemi että sen rajat muodostuvat enemmän suhteista ja vuorovaikutuksesta kuin systeemin komponenteista. Osat vaikuttavat kokonaisuuteen ja kokonaisuus osiin, eli systeemin suhteet ovat organisoituneet siten, että ne uusiutuvat jatkuvasti. Autopoieettisen systeemin yhtenäisyys syntyy aina tuloksena osatekijöiden lähikontakteista ja vuorovaikutuksesta, eli kommunikaatio on systeemiä ylläpitävä voima. Maturanan (1981, 21-23) mukaan autopoieettiset systeemit voidaan määritellä kokonaisuuksiksi, joissa komponentit synnyttävät verkoston ja verkosto synnyttää komponentit - eli osien välinen vuorovaikutus ylläpitää ja uusintaa verkostoa jatkuvasti, mutta toisaalta myös verkosto tuottaa ja ylläpitää osia. Autopoeettisen systeemin rajat muodostuvat niistä verkoston osista, jotka osallistuvat verkoston rakentamiseen.

Kaikki sosiaaliset systeemit ovat riippuvaisia jäsentensä välisestä kommunikaatiosta. Jos kom- munikaatiota ei ole tarpeeksi, systeemi ei voi olla toimiva - tai se ei edes välttämättä muodostu systeemiksi. Varelan mukaan "ymmärtääksemme kokonaisuutta meidän on osallistuttava siihen" (Varela \& Johnson, 1976, 31). Teorian mukaan siis passiivinen tai periaatteellinen kuuluminen itseuudistuvaan systeemiin on mahdotonta, koska siihen liitytään ja kuulutaan nimenomaan aktiivisen vuorovaikutuksen kautta.

Autopoieettisen systeemin suhde ympäristöön on erityinen: toisaalta systeemi tarvitsee ympäristöä elämänsä ylläpitämiseksi, mutta toisaalta se on kuitenkin operatiivisessa mielessä autonominen. Maturana ja Varela kirjoittavat, että ympäristö on autopoieettiselle systeemille viitekehys tai peili (point of reference) - eli systeemi elää suhteessa ympäristöönsä, mutta on samalla operatiivisesti itsenäinen systeemi (Maturana \& Varela, 1987, 75). Ympäristö toimii systeemille ikään kuin ”negatiivisena” peilinä, joka kertoo systeemille, mitä se ei ole. Siten systeemi käsittelee ja kirkastaa ydintään peilaamalla itsenään ympäristöön, ja tämän jatkuvan kommunikaation tuloksena se kykenee luomaan (ympäristöstä erottuvan) itsensä ja identiteettinsä.

Niinkin aikaisin kun 1976 Varela itse kuvasi autopoiesista sosiaalisen systeemin näkökulmasta. Oman systeemisen ytimen (identiteetin) rakentamisen päämäärä ja periaate pätee kaikissa autopoieettisissa systeemeissä, olkoon kyseessä sitten yksilö, organisaatio, yritys tai verkosto. Kuulumisen - eli samalla myös systeemin - rajojen määrittely on välttämätöntä identiteetin rakentumisen kannalta. Jos ei tiedä, miten erottuu ympäristöstä, ei voi tietää, kuka on. Varela määritteli systeemin olioksi, jolla on aina selkeät, mutta havainnoijasta riippuen vaihtelevat rajat. Eli käytännössä sosiaalisen systeemin rajojen määrittelijä on itsekin osa systeemiä ja määrittää rajat oman intressinsä mukaisesti. Kaikki sosiaaliset systeemit ovat itseensä viittaavia (self-referential), koska systeemi itse määrittelee itsensä (Varela \& Johnson, 1976, 26-31). Itseensä viittauksen logiikka voidaan kiteyttää näin: se mitä systeemi havaitsee, on aina heijastuma siitä, mitä se on. Varelan mukaan (Varela \& Johnson, 1976, 29) kaikki ne ominaisuudet, jotka erotamme mistä tahansa kohteesta, ovat aina riippuvaisia meistä itsestämme havainnoitsijana. Kohde ei siis avaudu ihmiselle objektiivisesti sen omasta olemuksesta käsin, vaan ihminen pystyy mieltämään kohteen vain omien ominaisuuksiensa läpi - osittain itse synnyttämän- 
sä vuorovaikutuksen tuloksena. Siten systeemin rajat määräytyvät toimijoittensa intressien mukaan ja kaikki systeemin ominaisuudet tulevat ilmaistuksi osittain toimijoiden omien ominaisuuksien kautta.

Perustavanlaatuinen ominaisuus autopoieettisissa systeemeissä on systeemin yhtenäisen rakenteen jatkuva uudelleen tuottaminen ("the constitution of the unity to be reproduced") (Maturana, 1981, 23). Autopoieettinen uudistuminen ei tarkoita ensisijaisesti muutosta, vaan autopoieettisen systeemin ytimen ylläpitämistä, johon systeemin ympäristöönsä tuottama vaikutus tai vetovoima perustuu.

Autopoieettisen systeemin kaksi tunnusomaista piirrettä ovat:

1) Vuorovaikutuksen kautta ilmenevä ydin. Systeemin perusolemusta ei voi ymmärtää, jos ei tutki siinä tapahtuvaa vuorovaikustusta. Autopoieettisen systeemin päätarkoitus on olemassaolo, jolle on tunnusomaista oman ytimen uusintaminen eli oman identiteetin jatkuvuus.

2) Systeemistä saa olennaista tietoa vain sen sisäpuolelta. Kun yksilö hahmottaa tai määrittää systeemiä, hän on jo osa sitä (Varela \& Johnson, 1976, s. 29). Määrittely on siis aktiivista osallistumista ja osallisuutta. Se on prosessi, jossa yksilön näkemys systeemistä muotoutuu vain vuorovaikutuksessa.
Autopoiesikseen perustuva uudistumisprosessi perustuu ytimen (identiteetin) selkeyteen, mutta myös tämän ytimen monistamiseen tai leviämiseen. Vain kirkas ydin voi erottua ja vain erottuva ydin voi olla vetovoimainen ja kertaantua.

\section{Stuart Kauffmanin evoluutiobiologia}

Yhdysvaltalainen Stuart Kauffmanin on biokemisti, teoreettinen biologi ja kompleksisuustutkija. Hänen evoluutiobiologiansa on suoraa jatkoa fysiikasta, kemiasta ja matematiikasta kumpuavalle kompleksisuustutkimuksen pitkälle traditiolle, mutta myös Prigoginen itseorganisoituvien systeemien sekä Maturanan ja Varelan autopoiesiksen tutkimukselle. Lisäksi Kauffman nojaa edeltäjiensä tavoin mm. Charles Darwinin ja Harold F. Blumin (mm. 1968) biologisten järjestelmien evoluutiotutkimukseen, mutta myös uudempiin itseuudistumisprosessia kartoittaneisiin tutkimuksiin, kuten Per Bakin (Bak \& Chen 1991) itseorganisoituvan kriittisyyden teoriaan sekä muun muassa Hollandin ja Gellmannin (mm. Holland 1998) esittämiin teorioihin kompleksisista, adaptiivisista systeemeistä.

Kauffman on tehnyt uransa Santa Fe Institute for Complex Studies -organisaatiossa, joka on tullut maailmalla tunnetuksi sekä useista (poikki)tie-

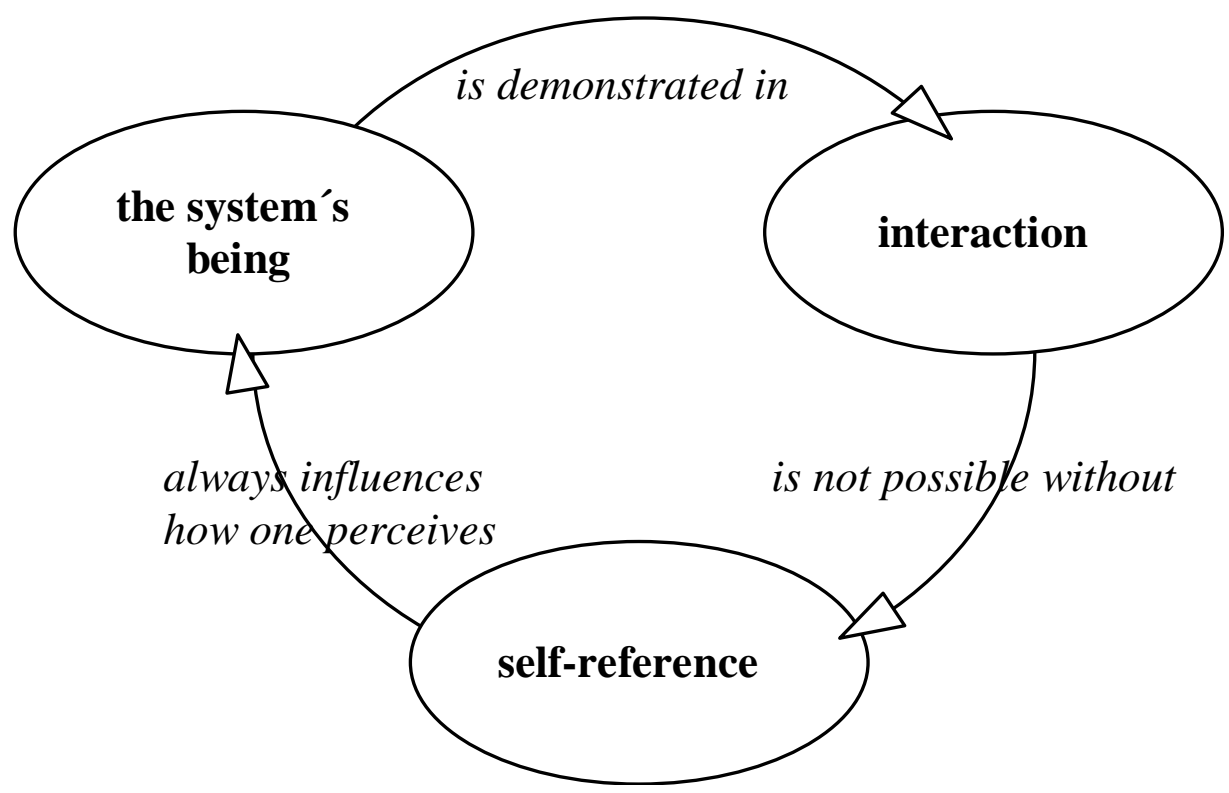

KUVA 1. Systeemin autopoieettinen luonne (Ståhle 1998, 81) 
teellisistä läpimurroistaan että monista fysiikan ja taloustieteen nobelisteistaan. Yhtenä mahdollisena tulevaisuuden nobelistinakin mainittu Kauffman kehitti jo lähes 40 vuotta sitten mallinsa satunnaisista verkostoista, jotka tuottavat "ilmaiseksi” itseorganisoitumista. Tämän jälkeen hän on tehnyt pitkän uran tutkiessaan mm. Prigoginen työn pohjalta itseorganisaatioprosessia ja emergenttiä järjestyksen syntymistä kaaoksesta sekä oppivien systeemien tapaa jakaa informaatiota ja sopeutua osaksi dynaamista organisaatiota. (1993, 1995, 2000, 2003, 2008).

Kauffmanin päätavoitteena on ollut selvittää ne perusmekanismit, jotka ohjaavat eläviä systeemejä. Tämän työn ei sinänsä voi sanoa tuoneen täysin uutta näkökulmaa tai läpimurtoa edellä esitettyihin Prigoginen tai Matuaranan \& Varelan systeemien autopoieettiseen itseuudistumiseen. Kauffman (2000; 2003) on kuitenkin onnistunut identifioimaan niiden rinnalle kolmannen itseuudistumiseen liittyvän perustendenssin. Hän osoitti, että dynaamisilla systeemeillä ${ }^{4}$ on paitsi mahdollisuus itseuudistumiseen ja siihen liittyvät ominaisuutensa, myös omat sisäänrakennetut päämääränsä ja aktiiviset pyrkimyksensä ${ }^{5}$. Tarkastelemme seuraavaksi kolmea Kauffmanin esittämää tendenssiä eli "ajuria”, jotka ohjaavat hänen mukaansa kaikkien dynaamisten systeemien toimintaa.

\section{Dynaamiset systeemit pyrkivät hyödyntämään maksimaalisesti avautuvia mahdollisuuksia (pursuit to adjacent possible).}

Kauffmanin (2000, 81-85, 207-209; 2003) mukaan kaikilla elävillä systeemeillä6 eli autonomisilla agenteilla (autonomous agents) on pyrkimys hyödyntää niille avautuvia mahdollisuuksia. Toisin sanoen elävät systeemit - riippumatta siitä ovatko ne dynaamisia, kuten ihminen, tai orgaanisia, kuten esimerkiksi bakteerit - testaavat autonomisina agentteina jatkuvasti erilaisia mahdollisuuksia pystyäkseen täyttämään ympäristössään avautuvia ekologisia lokeroita. Jos elävät systeemit pyrkisivät liian tehokkaasti tuottamaan variaatioita ja siten liian nopeasti täyttämään avautuvia mahdollisuuksiaan, ne tulisivat tuhonneiksi oman sisäisen rakenteensa yhdistävän mekanismin (internal gating mechanisms) ja heikentäisivät mahdollisuuttaan lisääntyä (propagate). Siksi elävillä systeemeillä on tietty luonnon valinnan mahdollistava optimivauhti, jolla ne hyödyntävät biosfäärissä avautuvia mahdollisuuksia siten, että ne samalla säilyttävät sisäiset mekanisminsa.

Kauffman tuo siis esiin, että kaikki elävät systeemit pyrkivät hyödyntämään niille avautuvia mahdollisuuksia. Hyödyntämisvauhdin (uudistumisen) tulee olla kuitenkin maltillinen ja suhteessa systeemin sisäiseen kantokykyyn, muuten systeemi on vaarassa tuhoutua. Tämä tuhoutumisen vaara - eli suhtautuminen tasapainoon - on nimenomaan se elementti, joka Prigoginen mukaan erottaa mekaaniset, orgaaniset ja dynaamiset systeemit toisistaan. ${ }^{7}$ Prigogine osoitti, että dynaamisten systeemien itseuudistuminen perustuu juuri siihen, että ne kykenevät altistamaan itsensä äärimmäisille paineille (fluctuations) ilman, että ne tuhoutuvat. Hajoamisen sijaan ne kykenevät itseorganisoimaan rakenteensa uudeksi, vanhaan palautumattomaksi rakenteeksi. Kauffman puolestaan korostaa kaikkien elävien systeemin sisäsyntyistä pyrkimystä hyödyntää avautuvia mahdollisuuksia - ei niinkään dynaamisten systeemien maksimaalista uudistumiskykyä. Kauffman tuo siten arvokkaan lisän myös dynaamisten systeemien ymmärtämiseen painottamalla sisäsyntyistä, aktiivista suuntautumista kohti uusia mahdollisuuksia. Sekä Prigogine että Maturana ja Varela kuvaavat tätä enemmän ainoastaan periaatteita, joilla uudistuminen tapahtuu.

2. Dynaamisilla systeemeillä on parhaat mahdollisuudet menestyä evoluutiossa, jos ne elävät mahdollisimman monimuotoisessa ja spontaanissa vuorovaikutusverkostossa (pursuit to edge of chaos).

Kauffmanin (1995; 2000, 159-188) mukaan kaikki dynaamiset autonomiset systeemit "pyrkivät kaikin keinoin” elämään mahdollisimman kompleksista elämää. Tämä tarkoittaa, että ne pyrkivät sekä elämään kaukana tasapainosta että maksimoimaan toimintaverkkonsa linkkien ja solmujen määrän. Kun ryhmällä vuorovaikutuksessa olevia autonomisia toimijoita on tämä sama päämäärä, koko ryhmä siirtyy kohti kaaoksen rajaa (edge of chaos), missä vallitsee samanaikaisesti rakentava yhteistyö, työnjako ja kova kilpailu. Eläminen tämän kaltaisella kaaoksen rajalla tuottaa kriittisiä etuja koko systeemille: Ensinnäkin se mahdollistaa systeemiin kuuluville maksimaaliset mahdollisuudet elää mahdollisimman monimuotoista elämää, joka tarjoaa runsaasti uusiutumisen mahdollisuuksia. Toiseksi se mahdollistaa omaehtoisen erottautumisen 
muista yhteisevoluutiossa mukana olevista systeemeistä8.

Kauffman osoittaa, että mitä dynaamisempi systeemi on, sitä paremmin se menestyy. Dynaamisuus taas perustuu siihen, että pyritään hakemaan mahdollisimman paljon kontaktipintaa ja vuorovaikutusta ympäristöön, mutta samalla osataan ajaa omaa etua. Tässä Kauffman yhdistää sekä Prigoginen esittämät itseorganisoitumis- että Maturanan ja Varelan autopoiesis-teorian. Kauffman yhtyy Prigoginen itesorganisoitumisperiaatteisiin, mutta tuo korostetusti esiin sen tärkeän ominaisuuden, että kaikki dynaamiset systeemit pyrkivät kohti maksimaalista kompleksisuutta. Prigogine ottaa tämän ikään kuin annettuna itseorganisoituvien systeemien ominaisuutena, ei pyrkimuksenä. Lisäksi Kauffman korostaa, että tämä kaaoksen reunalla eläminen on samalla myös keino erottautua muista, mikä puolestaan on autopoiesisteorian ydin. Tosin Maturanan ja Varelan mukaan muista erottautuminen ei edellytä kaaosta, vaan ainoastaan ympäristön jatkuvaa hyödyntämistä itsen referenssinä.

\section{Systeemin pyrkimys toteuttaa omaa etuaan on autonomisen uudistumisen ydin \\ (pursuits of autonomous agents).}

Yksi autonomisen uudistumisen ytimistä on systeemien tendenssi toteuttaa omaa etuaan. Kaikkien dynaamisten tai muutoin elävien systeemien oma etu sisältää seuraavien kolmen elementin yhtaikaisen tavoittelun riippumatta niiden tyypistä, koosta tai kompleksisuuden asteesta:

- $\quad$ Elävä järjestelmä pyrkii elämään mahdollisimman kompleksista elämää, johon kuuluu evoluutiossa avautuvien uusien mahdollisuuksien hyödyntäminen.

- Elävä järjestelmä pyrkii lisääntymään.

- Elävä järjestelmä pyrkii varmistamaan sekä oman energian saantinsa että lisäämään omaa energian kulutustaan (varmistaakseen kahden edellisen tavoitteen saavuttamisen).

Näiden tavoitteiden yhteisenä sivutuotteena systeemi jatkuvasti uudistaa itseään. Uudistumisprosessissa ylläpitävänä mekanismina on runsas kommunikaation määrä sekä systeemin sisällä että systeemien välillä. Uudistumisprosessi itsessään noudattaa sekä Prigoginen kuvaamaa rakenteen itseorganisaatiota että Maturanan ja Varelan kuvaamaa autopoieettista oman ytimen (identiteetin) jatkuvaa uudistamista. Molemmat teoriat hahmottavat enemmän itseuudistumisprosessin sisäistä logiikkaa, kun taas Kauffman lisää tarkasteluun päämääräaspektin eli systeemin aktiivisen intressin tavoitella omaa etuaan. Kauffman on kuitenkin samoilla linjoilla autopoiesis- ja itseorganisoitumisteorioiden kanssa siitä, että mahdollisimman runsas kommunikaatio on dynaamisen systeemin ylläpitäjä. Samoin hän korostaa myös autopoiesiksen ydinperiaatetta, jonka mukaan systeemin ympäristöstä erottuva ydin on uudistumista ylläpitävä voima. Tosin hän tuo tämän esiin eräänlaisena itsekkyysprinsiippinä, kun taas autopoiesis korostaa systeemin ytimen tai identiteetin jatkuvaa vahvistamista ympäristön kautta tapahtuvan reflektion avulla.

\section{Käytännön merkitys}

Maapalloistumisen, turbelenssin ja verkostoitumisen lisääntyminen asettaa yksilöiden osaamiselle ja oppimiskyvylle entistä suurempia haasteita. Tätäkin tärkeämmäksi saattaa kuitenkin nousta yritysten, organisaatioiden, instituutioiden ja erilaisten sosiaalisten järjestelmien uudistumis- ja oppimiskyky. Yritysten kilpailuetu perustuu yhä enemmän kollektiiviseen kyvykkyyteen: nopeaan reagointiin, ennakoivaan toimintaan ja strategiseen ketteryyteen (Doz \& Kosonen, 2008). Myös innovaatiotalous tuottaa uudenlaista toimintalogiikkaa, jossa kollektiivinen osaaminen koostuu monen eri alan huippuosaajasta ja jossa sekä tulokset että riskit jakaantuvat yhteisölle tai yritysten muodostamalle verkostolle. Menestys "luovassa taloudessa” edellyttää myös vetovoimaisten brändien ja kaupunkien imagon tietoista rakentamista (Ståhle \& Wilenius, 2006). Nykymaailmassa pärjätään toimintalogiikalla, joka perustuu paljolti niihin itseuudistumisen periaatteisiin, joita olemme edellä käsitelleet.

Prigoginen käytännön anti liittyy paljolti siihen, millä edellytyksillä kollektiivi, yhteisö tai organisaatio kykenee jatkuvasti (jopa radikaalisti) uudistamaan itseään sisältäpäin. Koska uudistumisen perusedellytys on mahdollisimman runsas kommunikaatio ja keskinäinen palaute (iteraatio), organisaatiorakenteen tulee olla verkostoitunut ja ihmisten kestää epävarmuutta ja ristiriitoja (entropia). Mekaanisesti toimiva, ylhäältä säädelty, ainoastaan tuotantotehokkuuteen trimmattu organisaatio on tämän vastakohta: joutuessaan pai- 
neiden tai ristiriitojen kohteeksi se ei kykene luomaan uusia toimintamuotoja ja rakenteita, vaan hajoaa. Olipa kyse yrityksistä tai valtioista, itseorganisoituminen edellyttää johdolta herkkyyttä ja rohkeutta hyödyntää aikaikkunat (bifurkaatio). Prigoginen kuvaus itseorganisoitumisen periaatteista ja edellytyksistä on sovellettavissa kaikenlaisten yhteisöllisten prosessien ja organisaatioiden rakentamiseen silloin, kun niiden perustehtävä edellyttää luovuutta, innovatiivisuutta ja jatkuvaa uudistumiskykyä.

Maturanan ja Varelan teoria valottaa eniten sellaista uudistumista, joka liittyy systeemin sisäiseen olemiseen ja erottuvaan identiteettiin. Nykymaailman informaatiotulvassa tyylit, tuotteet ja brändit kopioituvat nopeasti ja erottuminen on yhä vaikeampaa, ja sen myötä myös ihmisten huomion ja kiinnostuksen herättäminen. Viime vuosina tämä on käynyt selväksi sekä yrityksille, kaupungeille että kansakunnille, joiden kaikkien on tehtävä työtä vetovoimaisen imagon tai brändin rakentamiseksi. ”Jonakin oleminen” onkin nykyään tärkeämpää kuin jonkin tekeminen. Maan, paikkakunnan, yrityksen tai tuotteen mielikuva perustuu siihen, miten ne ilmentävät sisintä laatuaan - identiteettiään - toiminnassaan ja vuorovaikutuksessaan ympäristön kanssa. Mielikuvaa voidaan kuitenkin myös kirkastaa tietoisesti reflektoimalla itseään suhteessa ympäristöön, jolloin tulee entistä tietoisemmaksi omasta erityislaadustaan, pystyy kommunikoimaan siitä entistä paremmin ja levittämään sitä tehokkaasti. Itseuudistuminen perustuukin oman identiteetin tai ytimen jatkuvaan prosessointiin, selkeään tiedostamiseen ja kykyyn kiteyttää se. Auttava esimerkki autopoiesiksesta yritysmaailmassa on franchising-liiketoiminta, vaikkapa McDonalds. Kun bisnes on tarkoin määritelty ja brändinä vetovoimainen, sen monistaminen etenee nopeasti. Ehkä vielä parempia esimerkkejä löytyy muodin maailmasta, jossa identiteetit (tyylit, brändit) leviävät joskus itsestään kuin epidemiat. ${ }^{9}$ Tällöin systeemin itseuudistumisessa on juuri kyse ytimen erottumisesta ja vetovoimasta sekä näiden tuottamasta itseorganisoivasta voimasta ympäristössään.

Kauffman täydentää näitä näkökulmia korostamalla, että itseuudistuminen tapahtuu sitä tehokkaammin mitä monimuotoisemmasta ja spontaanimmasta vuorovaikutusverkostosta systeemi koostuu - olkoon sitten kyse itseorganisoitumisesta tai autopoiesiksesta. Kauffman korostaa myös aktiivisen asenteen merkitystä itseuudistuvan systee- min rakentumisessa: uudistumiskyky lisääntyy, kun mahdollisuuksia pyritään tunnistamaan aktiivisesti ja hyödyntämään maksimaalisesti. Autopoiesis uudistumisen perustana vahvistuu Kauffmanin mukaan, kun systeemi ajaa omaa etuaan. Tämän on kuitenkin oltava tasapainossa ympäristön edun kanssa, muutoin monimuotoinen ja spontaani yhteys ympäristöön ei voisi toteutua.

Itseuudistumisen teoreettinen ymmärtäminen on perusedellytys sille, että yhteiskunnan kaikenlaisten systeemien uudistumiskykyä osataan kehittää päämäärätietoisesti ja tuloksellisesti. Prigogine, Maturana, Varela ja Kauffman antavat tärkeitä välineitä tähän työhön.

\section{Lopuksi}

Systeemien itseuudistuminen on äärimmäisen haastava ilmiö sekä teoriassa että käytännössä - eikä sitä ole suinkaan tässä artikkelissa esitellyillä teorioilla loppuun ammennettu. On useita teoreettisia malleja ja itseuudistumisen periaatteita (esimerkiksi kompleksiset, adaptiiviset systeemit ja kaaosteoriat). Nämä vaativat oman analyyttisen tarkastelunsa, jotta ymmärryksemme systeemien itseuudistumisesta muodostuisi mahdollisimman monipuoliseksi ja olisi tieteellisesti riittävän luotettavalla pohjalla.

Itseuudistumisen sosiaalinen sovellettavuus tuo analyysin luotettavuuteen oman haasteensa. Suuri osa itseuudistuvien systeemien tutkimuksesta perustuu luonnontieteisiin, joista löydetyt periaatteet on tulkittu kaikkia systeemejä koskeviksi universaaleiksi lainalaisuuksiksi. Osittain tämä yleistys perustuu siihen, että luonnontietieteisiin keskittyneet systeemitutkijat ovat sittemmin laajentaneet tutkimusalaansa (kuten Kauffman ja Varela) tai olleet itse sitä mieltä, että löytyneet lainalaisuudet ovat universaaleja ja soveltuvat myös sosiaalisten systeemien toimintaan (Prigogine ja Maturana). ${ }^{10}$ Tämän hetkisen tutkimuksen pohjalta on vahva tieteellinen peruste olettaa, että itseuudistumisen systeemiset lainalaisuudet olisivat universaaleja. Tästä huolimatta kyseessä on vain hyvin perusteltu, joskin yhä enemmän tukea saanut hypoteesi.

\section{Lähteet}

Aalto, Hanna-Kaisa, Ahokas, Ira \& Kuosa, Tuo- 
mo (2008). Yleissivistys ja osaaminen työelämässä 2030 - Menestyksen eväät tulevaisuudessa. TUTU-Julkaisuja 1/2008, Finland Futures Research Centre, Turku School of Economics, ISBN 978-951-564-545-6.

Aldrich, H. (1999). Organizations Evolving. London: Sage.

Bak, Per \& Chen, Kan (1991). Self-organised Criticality. Scientific American, January, 2633.

Blum F. Harold (1968). Time's Arrow and Evolution, Princeton, Princeton University Press, ISBN-13: 978-0691023540.

Campbell, D. T. (1969). Variation and Selective Retention in Socio-Cultural Evolution. General Systems, 14, 69-85.

Castells, Manuel (1996). Rise of the Network Society: The Information Age: Economy, Society and Culture. Blackwell Publishers, Inc. Cambridge, MA, USA.

Chesbrough, H. (2006). Open Business Models, How to Thrive in the New Innovation

Landscape. Boston, Mass, Harvard Business School Press.

Doz, Y. \& Kosonen, Mikko (2008). Nopea strategia. Talentum: Helsinki

Gladwell, Malcolm (2000). The Tipping Point: How little Things Can Make a Big Difference. New York, Little Brown.

Hakkarainen, Kai (2006). Kollektiivinen älykkyys. Psykologia 06/03, 384-401.

Holland, John H. (1998): Emergence: From Chaos to Order. New York, Oxford University Press, ISBN 978-0-19-286211-2.

Hautamäki, Antti (2007a). Innovaatioiden ekosysteemi kaupunkipolitiikan ytimessä, Innovationsekosystem i stadspolitikens kärna. Kvartti 2/2006, 7-15.

Hautamäki, Antti (2008). Kestävä innovointi. Innovaatiopolitiikka uusien haasteiden edessä. Sitran raportteja 76. Sitra. Helsinki.

Kauffman, Stuart (1995). At Home in the Universe: The Search for the Laws of Self-Organization and Complexity. New York, Oxford University Press, ISBN-13 978-0195111309.

Kauffman, Stuart (2000). Investigations. New York, Oxford University Press, ISBN 0-19512104-x

Kauffman, Stuart (2003). The Adjacent Possible. www.edge.org, edited by John Brockman, 11.3.03, http://www.edge.org/3rd_culture/ kauffman03/kauffman_index.html

Kuosa, Tuomo (2007a). A Few Extensions to Path-dependence and Emergence in Complex Social Systems. Emergence: Complexity\& Organisations (E:CO). Issue Vol. 9 No. 4 2007, 3-16, ISSN 1521-3250.

Kuosa, Tuomo (2006). 40-vuoden tutkintomalli. Futura 1/2006.

Kuosa, Tuomo (2005a). Study on Logics on Society's Macro-level Transformation: A Macrohistorical Comparison of Pentti Malaska's Theory of Societal Change Compared to Other Theories of Transformation. Journal of Futures Studies (JFS). 10 (1) 2005. ISSN 1027-6084. 15-30.

Kuosa, Tuomo (2005b). Heikko signaali vai merkityksetön kohina: Pattern management - ontologisesti uusi lähestymistapa heikkojen signaalien ja tarkasteluun ja tulkintaan. Futura 4/2005, ISSN 0785-5494, 115-120.

Luhmann, Niklas (1990a). Ecological Communication [Ökologische Kommukation in german]. Westdeutscher Verlag, Oplanden/Wiesbaden.

Luhmann, Niklas (1990b). Essays of Self Reference. New York, Columbia University Press. ISBN: 02310636887.

Luhmann, Niklas (1995a). Social systems. Stanford, CA: Stanford University Press.

Malaska, Pentti (2003b): Synchronic - Diachronic System Analysis. In Rune Höglund Markus Jäntti - Gunnar Rosenqvist (eds.): Statistics, Econometrics and Society: Essays in honour of Leif Nordberg. Statistics Finland Research Report 238. Helsinki.

Malaska, Pentti (1991a). Economic and Social Evolution: The Transformational Dynamics Approach. In Publication Ervin Laszlo (ed.): The New Evolutionary Paradigm: The World Futures General Evolution Studies. Volume 2. The Vienna Academy for Global and Evolutionary Studies, Austria, ISBN 2-88124-375-4.

Malaska, Pentti (1991b). A Conceptual Framework for the Self-reliant Transformation of Africa. In Akilu Lemma \& Pentti Malaska (eds.): Africa Beyond Famine: A report to the Club of Rome. African Studies Review, 34 (2), ISSN 00020206, 158-159. 
Maturana, Humberto R. \& Varela, Francisco J. (1992): The Tree of Knowledge: The Biological Roots of Human Understanding. London, Shambhala, ISBN-13: 978-0-87773642-4.

Maula, Marketta. (1999): Multinational companies as learning and evolving systems. A multiple-case study of knowledge-intensive service companies. An application of autopoiesis theory. Helsinki School of Economics and Business Administration. Acta Universitatis Oeconomicae Helsingiensis. A-154. Helsinki.

Nicolis, Grégoire \& Prigogine, Ilya (1989): Exploring Complexity: An introduction. New York, Freeman and Company, ISBN-13: 9780716718598.

Nicolis, Gregoire \& Prigogine, Ilya (1977): Selforganization in non-equilibrium systems: From dissipative structures to order through fluctuations. New York: Wiley.

Prigogine, Ilya \& Stengers, Isabelle (1984): Order out of Chaos: Man's New Dialogue with the Nature. New York, Bantam Books, ISBN13: 978-0394542041.

Prigogine, Ilya (1967a). Dissipative process, quantum states and field theory. XIVe Conseil de Physique Solvay. Oct. 1967. Bruxelles.

Prigogine, Ilya (1967b): Introduction to thermodynamics of irreversible processes (3rd. ed.). New York: Wiley.

Prigogine, Ilya (1967c). Quantum theory of dissipative systems and scattering processes. Nobel Symposium V. Stockholm.

Prigogine, Ilya (1976): Order through fluctuations: Self-organization and social systems. In E. Jantsch \& C. H. Waddington (Eds.), Evolution and consciousness: Human systems in transition (pp. 93-133). Reading, MA: Addison-Wesley.

Prigogine, Ilya (1980). From being to becoming: Time and complexity in the physical sciences. San Francisco: Freeman.

Prigogine, Ilya \& Lefever, R. (1973). Theory of dissipative structures. In Synergetics cooperative phenomena in multi-component systems. Proceeding of the Symposium on Synergetics, from April 30 to May 6, 1972, Schloss Elmau. Ed. by H. Haken. Pub. B.G. Stuttgart.

Prigogine, Ilya \& Stengers, Isabelle (1984). Or- der out of chaos: Man's dialogue with nature. New York: Bantam.

Prigogine, Ilya \& Nicolis, Gregoire (1989): Exploring complexity: An introduction. New York: Freeman.

Pöyhönen, Aino (2004): Modelling and measuring organizational renewal capability. Lappeenranta: Acta Universitatis Lappeenrantaensis 200: Digipaino

Rapoport (1986). General Systems Theory: Essential concepts and applications. Tunbridge Wells: Abacuss Press.

Ståhle, Pirjo (1998): Supporting a System's Capacity for Self-renewal. Research Report 190, Department of Teacher Education, University of Helsinki. Pages 393.

Ståhle, Pirjo \& Grönroos, Mauri (1999). Knowledge Management - tietopääoma yrityksen kilpailutekijänä. Helsinki: WSOY.

Ståhle, Pirjo \& Pöyhönen Aino (2003). Analyzing Organization's Dynamic Intellectual Capital. A System-based theory and application. Acta Universitatis Lappeenrantaensis 152. Lappeenranta.(pp.191)

Ståhle, Pirjo, Kyläheiko, K., Sandström, J. \& Virkkunen,V. (2002). Epävarmuus hallintaan yrityksen uudistumiskyky ja vaihtoehdot. Helsinki: WSOY.

Ståhle, Pirjo, Pöyhönen, A. \& Kyläheiko, K. (2003). Towards Operationalization of Dynamic Capabilities. In Y. Hosni (Ed.) Internet Economy: Opportunities and Challenges for Developed and Developing Regions of the World. Elsevier.

Ståhle, Pirjo \& Wilenius, Markku (2006). Luova tietopääoma - tulevaisuuden kestävä kilpailuetu. Helsinki: Edita.

Von Hippel, Eric (2005). Democratizing Innovation. Cambridge, Mass, The MIT Press.

Weick, Karl (1979). The Social Psychology of Organizing (Second ed.). London: AddisonWesley.

\section{Viitteet}

1. Maturanan \& Varelan ohella merkittäviä sosiaalisiin organisaatioihin liittyviä autopoiesiksen teorioita ovat esittäneet Niklas Luhmann (1990a; 1990b) sekä mm. Pentti Malaska (1991a; 1991b; 
2003), joiden teorioihin emme tässä yhteydessä kuitenkaan syvenny enempää. Kts. Luhmannin te orian tarkastelu (Ståhle, 1998) ja Malaskan (Kuosa, 2005a).

2. Kauffmanin käsite dynaaminen systeemi vastaa Prigoginen käyttämää dissipatiivista systeemiä. Molempien tunnuspiirteenä on kyky spontaaniin itseorganisoitumiseen. Kts. mekaanisten, orgaanisten ja dynaamisten systeemien käsite- ja paradigma-analyyysi Ståhle 1998, 13-45 ja sovellus organisaatioihin Ståhle \& Grönroos 1999.

3. Kannattaa huomioida, että itse evoluutiossa vuorottelevat variointi, valikointi ja vakiinnuttaminen (esim. Weick 1979; Campbell 1969; Aldrich 1999), mikä on tavallaan ylätason itseuudistumisprosessi. Kauffman tutkii nimenomaan evoluution reunaehtoja, joita kaikki elävät systeemit itseuudistumisessa noudattavat kehitysasteesta riippumatta. Toisin sanoen bakteeripopulaatio ja koulujärjestelmä ovat keskenään hyvin erilaisia, mutta molemmat ovat silti eläviä järjestelmiä, joilla on näin ollen monia yhteisiä piirteitä. Siten Kauffman useiden systeemiteoreetikkojen tapaan pitää systeemisiä ominaisuuksia universaaleina, kontekstista riippumattomina.

4. Tässä artikkelissa keskitytään tarkastelemaan dynaamisten systeemien itseuudistumisen periaatteita. Kauffman kuitenkin sisällyttää omassa työssään eläviin systeemeihin sekä orgaaniset, avoi- met systeemit että dynaamiset, radikaalisti itseorganisoituvat systeemit, koska molemmat ovat eläviä erotuksena täysin mekaanisista systeemeistä. Systeemejä, jotka ovat eläviä, Kauffman nimitttää yleisesti autonomisiksi agenteiksi.

5. Kts. systeemien analyyttinen tarkastelu Ståhle 1998, 13-46.

6. Arkipäivän esimerkkinä voimme pohtia yksilön elämää suurkaupungin vilinässä vs. maaseudun rauhassa. Hektinen ja lähellä kaaosta oleva cityelämä avaa jatkuvasti uusia ja ennakoimattomia mahdollisuuksia eteen ja mahdollistaa omaehtoisen erottautumisen, kun taas maaseutuelämä on sidoksissa yksilön omaan aktiivisuuteen ja vähiin mutta melko kiinteisiin naapuruussuhteisiin.

7. Malcom Gladwell kuvaa ilmiötä kirjassaan Leimahduspiste (2007).

8. Niklas Luhman on esittänyt oman sovelluksensa autopoiesiksen pohjalta, eli teorian itseensä viittaavista systeemeistä (self-referential systems), joka kuvaa nimenomaan sosiaalisten systeemien itseuudistumista (Luhmann, 1995). Teoria vaatii oman perusteellisen tarkastelunsa, johon voi tutustua mm Ståhle, 1998.

Artikkeli saapui toimitukseen22.9.2008.

Se hyväksyttiin julkaistavaksi toimituskunnan kokouksessa 16.3.2009. 